\title{
The family Rhynchocinetidae Ortmann \\ (Crustacea, Decapoda, Caridea) on the Brazilian coast
}

\author{
Gustavo A. S. de Melo
}

M useu de Zoologia, Universidade de São Paulo. Caixa Postal 42594, 04299-970 São Paulo, Brasil. Bolsista do CN Pq. E-mail: gasmelo@usp.br

\begin{abstract}
The family Rhynchocinetidae Ortmann, 1890, presently in the superfamily Nematocarcinoidea Smith, 1884 and the genus Rhynchocinetes H. Milne Edwards, 1837, has always had a complex and controversial classification. Until recently, the only species known from the Brazilian coast was Rhynchocinetes rigens Gordon, 1936, which was transferred to the genus Cinetorhynchus. Rhynchocinetes typus H. Milne Edwards, 1837, the typespecies of the genus, was known only from the eastern Pacific; but in the carcinological collection of the Museu de Zoologia da Universidade de São Paulo, a specimen of this species collected at Ubatuba, São Paulo was found; this is the first record of this species for the Brazilian coast. These two species are redescribed and illustrated. KEY WORDS. Brazilian waters; Cinetorhynchus; redescriptions; Rhynchocinetes.
\end{abstract}

RESUMO. A família Rhynchocinetidae Ortmann (Crustacea, Decapoda, Caridea) no litoral brasileiro. A família Rhynchocinetidae Ortmann, 1890, atualmente na superfamília Nematocarcinoidea Smith, 1884 e o gênero Rhynchocinetes H. Milne Edwards, 1837, sempre tiveram uma discutida e complexa classificação. Até recentemente, no litoral brasileiro, a única espécie conhecida era Rhynchocinetes rigens Gordon, 1936, que foi transferida para o gênero Cinetorhynchus. A espécie Rhynchocinetes typus, espécie-tipo do gênero, só era conhecida do Pacífico oriental, mas na coleção carcinológica do Museu de Zoologia da Universidade de São Paulo, foi encontrado um exemplar desta espécie coletado em Ubatuba, São Paulo, que é o primeiro registro desta espécie para o litoral brasileiro. As duas espécies da família são redescritas e ilustradas.

PALAVRAS-CHAVE. Costa brasileira; Cinetorhynchus; redescrições; Rhynchocinetes.

The species of the family Rhynchocinetidae are characterized by having a movable rostrum, by fine transverse striae on the surface of the carapace and abdominal somites, by having the first two pairs of pereiopods more robust than the others, the fingers of the chelipeds with long lateral and terminal spines, and the second pereiopods with carpus entire, not subdivided (OKuno 1996).

The genus Rhynchocinetes, as presently recognized, can be divided into two natural groups, as suggested by GoRDON (1936) in his revision of the genus. According to Holthuis (1995), the numerous species described after the work of Gordon have only confirmed the differences between these two groups, which could be established as subgenera: Rhynchocinetes $\mathrm{H}$. Milne Edwards, 1837 s. str. (wherein Rhynchocinetes typus H. MilneEdwards, 1837 was included) and Cinetorhynchus Holthuis, 1995 (to which Rhynchocinetes rigens Gordon, 1936 was assigned). OKUno (1997) elevated these two subgenera to genus rank, as they are presently treated.

Gomes-CorrêA (1971) signaled the first occurrence of Rhynchocinetes rigens on the Brazilian coast, with material (three ovigerous females) collected in Tamandaré Bay, Pernambuco.
This species was previously known from Florida, the Bahamas, and the Bermuda Islands in the Western Atlantic, and the Madeira Island and the Azores in the Eastern Atlantic.

During an examination of the carcinological collection of the Museu de Zoologia da Universidade de São Paulo, one specimen (MZUSP 10913) was found of Rhynchocinetes typus, originating from Ubatuba on the northern coast of São Paulo. Up to now, the known distribution of this species was limited to the Eastern Pacific (Chile, Peru and Ecuador).

\section{Rhynchocinetidae Ortmann, 1890}

Rhynchocinetidae Ortmann, 1890: 459; Stebbing, 1917: 26; Gordon, 1936: 75; Burkenroad, 1939: 310; Barnard, 1950: 762; Holthuis, 1955: 40; 1980: 79; Miranda \& Kong U., 1970: 42; Fonseca, 1970: 19; Mendez, 1981: 69; Bruce, 1984: 209; Retamal, 1994: 25; Hendrickx, 1995: 424; Okuno, 1996: 325; 1997: 43; Ramos-Porto \& Coelho, 1998: 328; Udekem d'Ácoz, 1999: 92.

Rhyncocinetidae Sharp, 1893: 118.

Rhynchocynetidae Borradaile, 1907: 467.

Rynchocinetidae Gurney, 1939: 72

Revista Brasileira de Zoologia 24 (1): 57-63, março 2007 
Key to genera and species of Rhynchocinetidae in Brazil

1. Two dorsal teeth on carapace behind base of rostrum. Postorbital spine present, rarely reduced to a tubercle. Suborbital angle distinct, located above antennal spine. Posterior margin of abdominal somites 4 and 5 without spine above base of pleura. Rostrum articulation complete Rhynchocinetes typus

1 '. Three dorsal teeth on carapace behind base of rostrum. Postorbital spine absent. Suborbital angle continuous with antennal spine. Posterior margin of somites 4 and/or 5 with distinct spine. Rostrum articulation sometimes incomplete Cinetorhynchus rigens

\section{Cinetorhynchus rigens (Gordon, 1936)}

Figs 1-10

Rhynchocinetes rigens Gordon, 1936: 75; text-fig. 1-7; Burkenroad, 1939: 311; Gurney, 1940: 113, text-fig. 8-10; Figueira, 1960: 1; Manning, 1961: 1, figs 1-2; Gomes-Corrêa, 1971: 105, fig. 1-10; Chace, 1972: 17; Coelho \& Ramos, 1972: 144; Ramos-Porto \& Coelho, 1998: 328.

Rhynchocinetes (Cinetorhynchus) rigens; Holthuis, 1955: 145.

Cinetorhynchus rigens; Okuno, 1997: 33; Udekem d'Acoz, 1999: 92.

Description: rostrum long, curved upwards, extending far beyond scaphocerite; dorsal face with about five teeth, three proximal teeth larger and more spaced, and two distal teeth smaller and closer together; ventral face with nine teeth, three proximal teeth more developed and curved, and remaining teeth much smaller and more spaced; a longitudinal crest on each lateral face of rostrum; articulation of rostrum with carapace incomplete, allowing only vertical movement. Carapace with inconspicuous vertical striae and with three stout teeth in front of articulation with rostrum, first two teeth closer together; supra-orbital spine absent. Scaphocerite narrowing distally and with stout teeth on outer margin, which extends past extremity of lamina. Antennal spine continuous with lower edge of orbit; pterogostomial angle rounded. Eyes large and rounded, cornea much wider than peduncle. Third maxillipeds nearly reaching extremity of scaphocerite. Chelipeds reaching extremity of antennal peduncle, merus with small distal lobe; carpus more than half length of palm, and palm three times length of fingers; dactylus and fixed finger terminating in several corneous spines. Ambulatory legs more slender than chelipeds, and all reaching or exceeding basal article of antenna; merus with 4-7 movable spines, carpus generally with one spine and ischium with two spines. Abdomen also with fine striae equal to those of carapace; pleura of first and third somites with oblique groove; first somite with rounded pleura and third somite terminating in point; fourth and fifth somites with small tooth on each side. Telson long, terminating in acute point and with three pairs of terminal spines: outer lateral spines diminutive, inner lateral spines longest, and mesial spines long but smaller than anterior spines; dorsal face of telson with three pairs of spines: first pair located at level of mid-telson, second and third pairs on distal third.

Geographical distribution: Western Atlantic - Bermuda Islands, Florida, Bahamas, Virgin Islands and Brazil (Pernambuco and Espírito Santo). Eastern Atlantic - Madeira Island, Azores.

Material examined: BrASIL, Pernambuco: Tamandaré Bay, Municipality of Rio Formoso, S. Ypiranga Pinto coll., February 1967, three ovigerous females (MNRJ- 2284). Espírito Santo: Ilha dos Franceses, Marataizes, Gasparini \& Floeter coll., 12.III.1997, one ovigerous female (MZUSP- 12920).

Remarks: the material examined, in general, concords with the description of the type-material by GoRDON (1936), but some differences were noted. The type-specimen has a rostrum with eight teeth on the lower face, whereas the Brazilian specimens have nine teeth; and the articulation of the rostrum of the holotype nearly reaches the longitudinal crest, which is not the case with the specimens examined, in which the articulation is much shorter. According to MANNING (1961), the rostral articulation is not visible in specimens less than $6.0 \mathrm{~mm}$ in carapace length. In large specimens, the rostrum is shorter in the females than in the males. In the specimensfrom Espírito Santo, the basal segment of the scaphocerite bears two strong spines, which are not mentioned in the works of GORDON (1936) and Gomes-CorrêA (1971). The occurrence of Cinetorhynchus rigens in Espírito Santo represents the southernmost limit of the species in the South Atlantic.

\section{Rhynchocinetes typus H. Milne Edwards, 1837 Figs 11-20}

Rhynchocinetes typus H. Milne Edwards, 1837a: 383; 1837b: 168; H. MilneEdwards \& Lucas, 1843: 36; White, 1847: 130; Nicolet, 1849: 246; Gibbes, 1850: 197; Heller, 1865: 120; Cunningham, 1871: 497; Miers, 1876: 77; Filhol, 1885: 52; 1886: 430; Ortmann, 1890: 507; Sharp, 1893: 118; Lenz, 1902: 734; McCulloch, 1909: 312; Rathbun, 1910: 562; Stebbing, 1920: 27; Kemp, 1925: 264; Gordon, 1936: 83; Holthuis, 1947: 78; Retamal, 1981: 14; Correa, Baeza, Hinojosa \& Thiel, 2003: 33. Rhynchocinetes typicus; Dana, 1852: 568; 1855: 12; Porter, 1940a: 147; 1940b: 313; 1941: 460.

Description: rostrum relatively long, curved upwards, reaching past the scaphocerite; upper face with two well-spaced proximal teeth on the movable part and another two behind the orbit, above the carapace and six or seven teeth in the distal third; lower face with 17 teeth, the six distal teeth with more distance between them and the remainder very closely set and less acute; distal extremity with four small teeth, and three much smaller teeth behind. Articulation of rostrum with carapace complete; next to articulation is a stout, anteriorly pointing tooth. Supra-orbital spine strong and directed forwards. Scaphocerite narrowing distally and with stout distal spine on its outer margin, which reaches past the lamina; inner margin completely provided with setae. Antennal spine continuous with lower bor- 

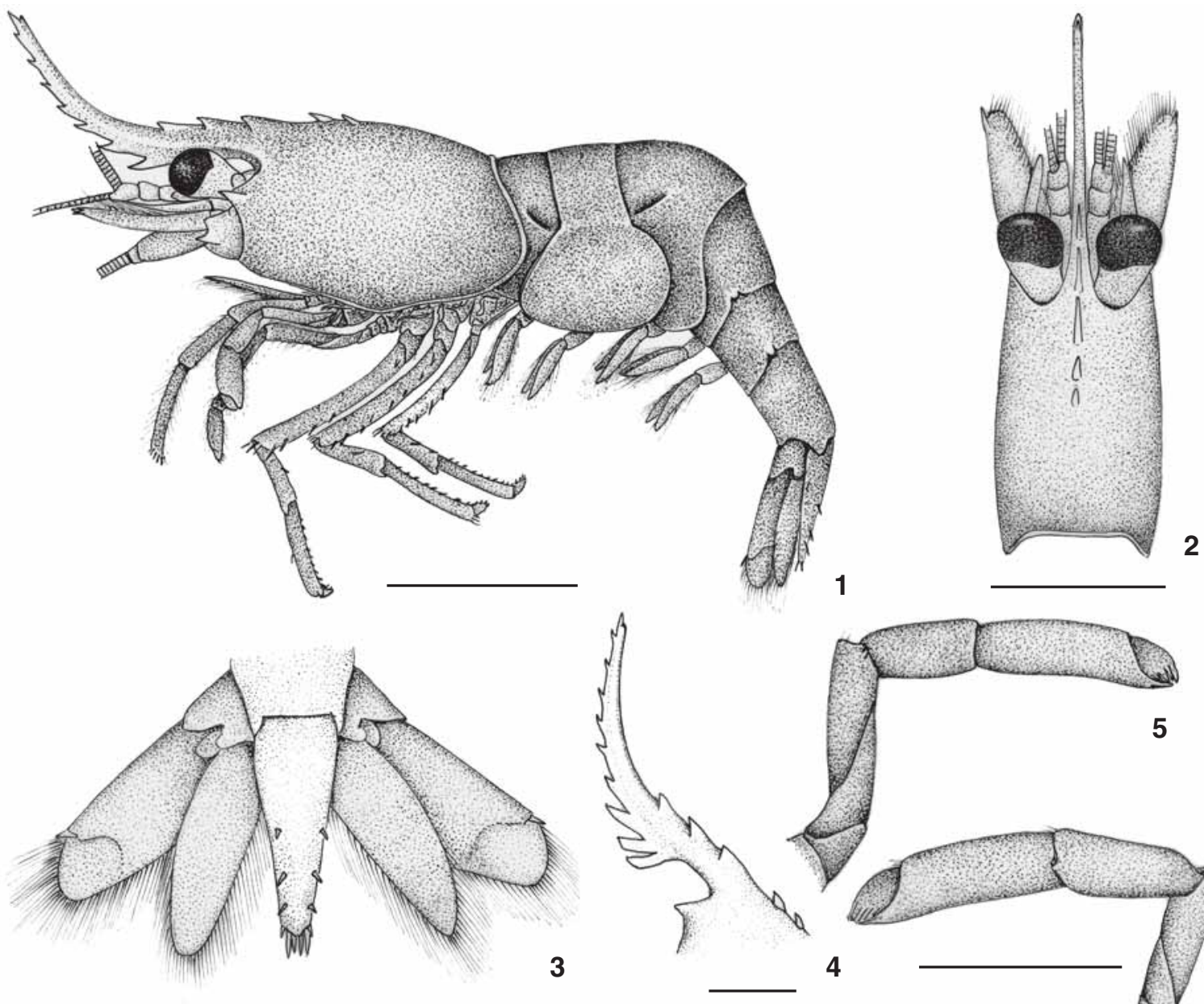

1

2
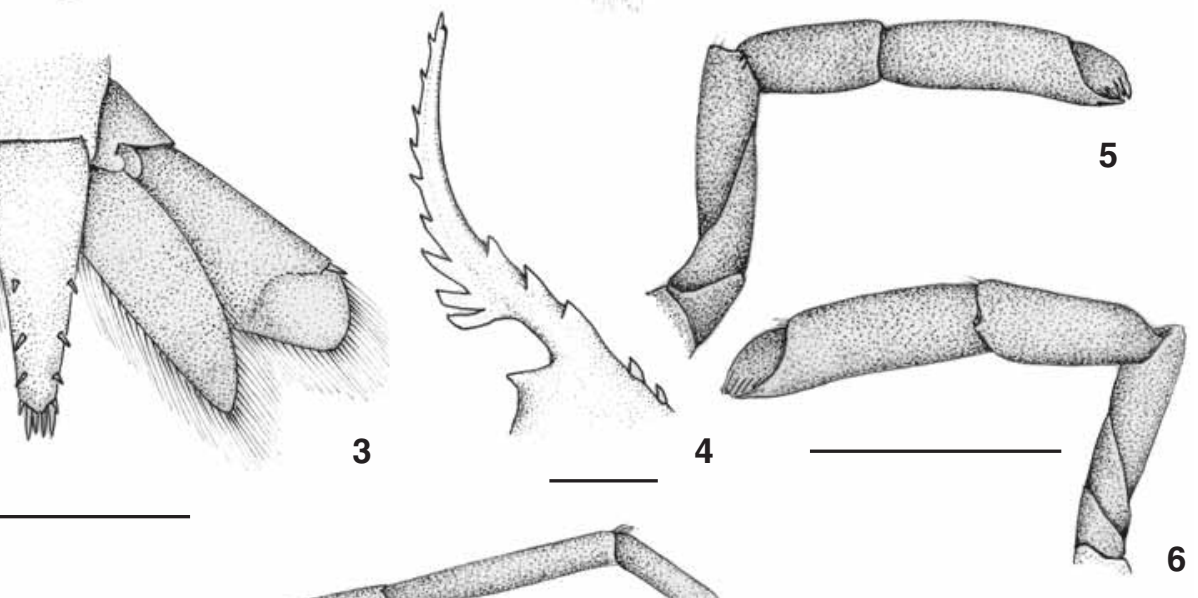

6

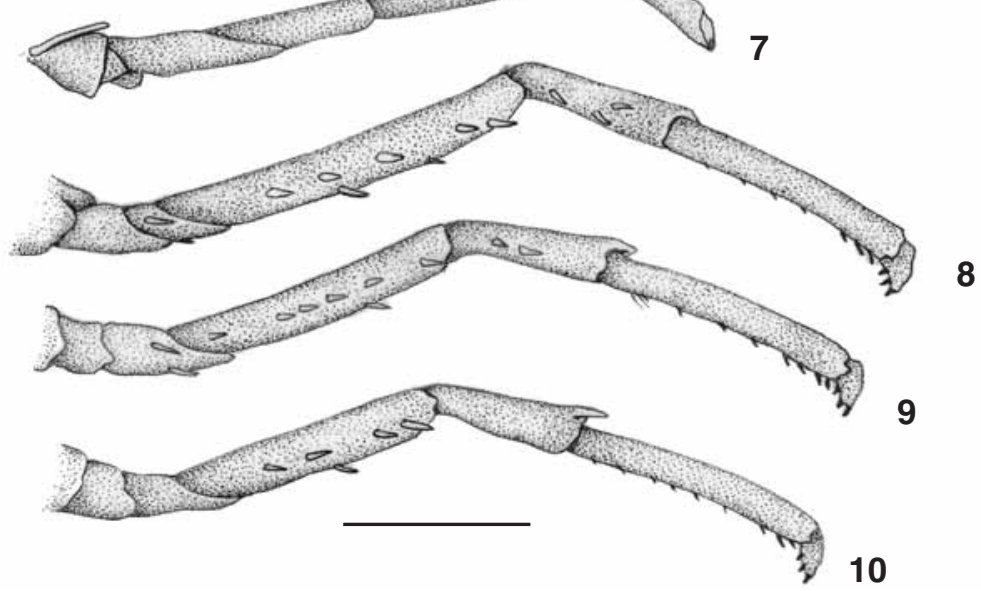

Figures 1-10. Cinetorhynchus rigens, Ilha dos Franceses, Espírito Santo, ovigerous female, MZUSP 12920: (1) lateral view; (2) carapace, dorsal view; (3) telson and uropods, dorsal view; (4) rostrum, lateral view; (5) left cheliped, mesial view; (6) right cheliped, mesial view: (7) second pereopod, lateral view; (8) third pereopod, lateral view; (9) fourth pereopod, lateral view; (10) fifth pereopod, lateral view. Scale bars: (1-2) $8 \mathrm{~mm}$; (3) 10mm; (4) $7 \mathrm{~mm}$; (5-10) $6 \mathrm{~mm}$. 


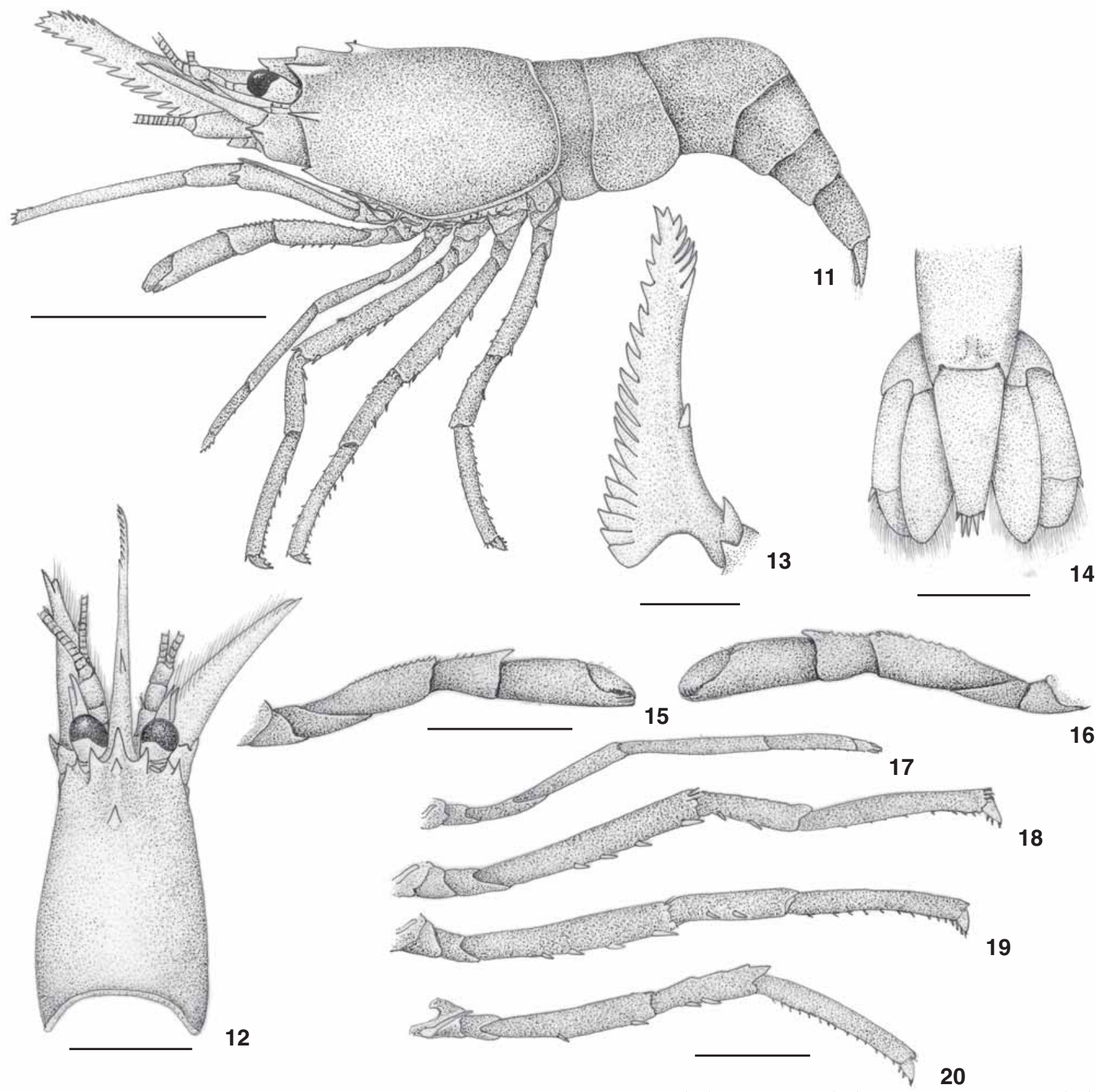

Figures 11-20. Rhynchocinetes typus, Ubatuba, São Paulo, female, MZUSP 10913: (11) lateral view; (12) carapace, dorsal view; (13) rostrum, lateral view; (14) telson and uropods, dorsal view; (15) left cheliped, mesial view; (16) right cheliped, mesial view; (17) second pereopod, lateral view; (18) third pereopod, lateral view; (19) forth pereopod, lateral view; (20) fifth pereopod, lateral view. Scale bars: (11) $16 \mathrm{~mm}$; (12) $8 \mathrm{~mm}$; $(13,15,16) 7 \mathrm{~mm}$; $(14,17-20) 5 \mathrm{~mm}$.

der of orbit. Eyes large and rounded, cornea much wider than peduncle. Third maxillipeds reaching past scaphocerites. Chelipeds not reaching extremity of antennal peduncle, with merus longer than carpus and with strong distal spine; merus and carpus with dorsal margin dentate: palm double the width of the fingers, which possess a corneal point and the hiatus between them covered by tufts of setae. First ambulatory leg more slender than the others and with unarmed segments. Second ambulatory leg with merus with four ventral teeth, the distal tooth larger; carpus half of merus and with two ventral teeth; propodus 
with line of small spines on ventral face, which increase in size distally; dactylus short. Third leg equal to second, but with bifurcate dactylus. Fourth ambulatory leg smaller than the others, with a single ventral subterminal spine on merus, and dactylus bifurcate. Abdomen smooth, without spines; pleura of first somite somewhat rounded, of second somite strongly rounded; somites 3-5 with pleura somewhat acute; third somite higher than others, forming a hump, after which the abdomen curves downwards; sixth somite double the fifth. Telson long, terminating in acute point and with three pairs of terminal spines: outer lateral spines diminutive, inner lateral spines longest, and mesial spines long but smaller than anterior spines; dorsal face of telson also with three pairs of spines: one pair on anterior half and two pairs on posterior half. Exopods of uropods with strong subdistal spine and endopods ovate, with tufts of setae along their entire length.

Geographical distribution: Eastern Pacific - Chile (Iquique, Cavancha, Antofagasta, Caldera, Coquimbo, Viña del Mar and Valparaíso), Peru (Lobos de Afuera), Ecuador (Galápagos). Western Atlantic - Brazil (Ubatuba, São Paulo).

Material examined: BrazıL, São Paulo: Ubatuba, H.R. Costa, coll., 12.IV.1965, 13 m, 1 ovigerous female (MZUSP-10913). Chile, Viña del Mar, Gomes-Corrêa coll., 28.I.1988, 4 females (MNRJ-2701)

Remarks: Holthuis (1951: 67) explained that in the course of his revision of the species of Rhynchocinetes, GoRDon (1936) found that many specimens of R. typus from localities other than Chile belonged to other species; and that the type-locality of R. typus, indicated by $\mathrm{H}$. Milne Edwards as the Indian Ocean, was erroneously labeled. In reality, this species was known only from Chile, Peru and Ecuador (Galapagos).

\section{ACKNOWLEDGEMENTS}

The author is grateful to Cristiana Serejo (Museu Nacional do Rio de Janeiro) for making avaliable the material from their institution, and Jaime Roberto Somera for preparing drawings. The author also thank to CNPq (National Council for the De velopment of Science and Technology) for supporting studies on the systematics of decapod crustaceans in the form of ongoing grant (2004-304273-0).

\section{REFERENCES}

BARNARD, K.H. 1950. Descriptive catalogue of South African Decapod Crustacea (Crabs and Shrimps). Annals of South African Museum 38: 1-837.

BorRADAILE, L.A.1907. On the classification of the decapod crustaceans. Annals and Magazine of Natural History, series 7, 19 (114): 457-486.

BRUCE, A.J. 1984. A note on some specimens of Rhynchocinetes (Decapoda: Rhynchocinetidae) from Enewetak Atoll, Marshall Islands. Crustaceana 46 (2): 209-211.

BuRKENROAD, M.D. 1939. Some remarks upon non penaeid Crus- tacea Decapoda. Annalsand. Magazine of Natural History, series 11, 3 (15): 310-318.

ChACE, F.A., JR. 1972. The shrimps of the Smithsonian-Bredin Caribbean Expeditions, with a summary of the West-Indian shallow-water species (Crustacea: Decapoda: Natantia). Smithsonian Contribution to Zoology 98: 1-179.

Coelho, P.A. \& M. Ramos. 1972. A constituição e a distribuição da fauna de decápodos do litoral leste da América do Sul, entre as latitudes de 5 $\mathrm{N}$ e 39 o S. Trabalhos do Instituto Oceanográfico da Universidade Federal de Pernambuco 13: 133-236.

CorrêA, A.C.; J.A. Baeza; I.A; Hinojosa \& M. Thiel 2003. Male dominance hierarchy and mating tactics in the rock shrimp Rhynchocinetes typus (Decapoda: Caridea). Journal of Crustacean Biology 23 (1): 33-45.

Cunningham, R.O. 1871. Notes on Reptiles, Amphibia, Fishes, Mollusca and Crustacea obtained during the voyage of. H.M.S. "Nassau" in the years 1866-69. Transactions of the Linnean Society of London, Zoology 27: 465-502

DANA, J.D. 1852. Crustacea. Part I. In: United States Exploring Expedition during the years 1838, 1839, 1840, 1841, 1842 under the command of Charles Wilkes. U.S.N. London, vol. 13, p. 1-695.

DANA, J.D. 1855. Crustacea. In: United States Exploring Expedition during the years 1838, 1839, 1840, 1841, 1842 under the command of Charles Wilkes U.S.N. London, vol. 13 (Atlas), p. 1-127.

Figueira, A.J.G. 1960. On a small collection of decapod crustaceans from the Açores. Bocagiana 6: 1-13.

FilhoL, H. 1885. La vie au fond des mers. In: Les explorations sous-marines et les voyages du "Travailleur" et du “Talisman". Paris, p. 1-103.

FILHOL, H. 1886. Consi dérations relatives à la faune des Crustacés de la Nouvelle Zélande. Biblioteque de haut études 30: 160.

FonseCA, N.C. 1970. Lista de los crustáceos del Peru (Decapoda y Stomatopoda) com datos sobre su distribución geográfica. Informe del Instituto Marino del Peru 35: 25-36.

GIBBES, L.R. 1850. On the carcinological collections of the Natural History in the United States. Proceedings of the Third Meeting of American Association for Advancement of Science 3: 165-201.

Gomes-CorrêA, M.M. 1971. Sobre a ocorrência de Rhynchocinetes rigens Gordon no litoral brasileiro. Arquivos do Museu Nacional, 54: 105-107.

GoRDon, I. 1936. On the macruran genus Rhynchocinetes, with description of a new species. Proceedings of the Zoological Society of London 1936 (1): 75-88.

GuRney, R. 1939. Bibliography of the larvae of Decapod Crustacea. Royal Society of London 125: 1-123.

GuRnEY, R. 1940. The larval stages of Rhynchocinetes rigens Gordon, p. 113-124. In: R. Gurney, R. \& M.V. Lebour (Ed.). On the larvae of certain Crustacea Macrura, mainly from 
Bermuda. Journal of the Linnean Society of London 41 : 89-181.

Heller, C. 1865. Reise der österreichischen Fregatte Novara um die Erde in den Jahren 1857, 58unt, 59 er den Befehlen des commodors B. von Wüllerstorf-Urbair. Zool. Theil, zveiter Band, dritte Abtheilung, Crustaceen, Viena, 4: 1-280.

HendRICKX, M.E. 1995. Checklist of brachyuran crabs (Crustacea: Decapoda) from the eastern tropical Pacific. Bulletin de I'Institut Royal des Sciences Naturelles de Belgique, Biologie, 65: 125-150.

HolthuIS, L.B. 1947. The Decapoda of the Siboga Expedition. Part IX: The Hippolytidae and Rhynchocinetidae collected by the Siboga and Snellius Expeditions with remarks on other species. Siboga-Expeditie Monographie 39a (8): 1100.

HolthuIS, L.B. 1951. The Caridean Crustacea of Tropical West Africa. Atlantide Report 2: 1-187.

HolthuIS, L.B. 1955. The recent genera of the caridean and stenopodidean shrimps (Class Crustacea: Order Decapoda: supersection Natantia) with keys for their determination. Zoologische Verhandligen 26: 1-157.

Holthuis, L.B. 1980. FAO Species Catalogue. FAO Fisheries Synopsis. 125, vol. 1. Shrimps and praws of the world. An annotated catalogue of species of interest to fisheries. Roma, 271p.

HolthuIS, L.B. 1995. Notes on Indo-West Pacific Crustacea. Decapoda II to IX. Zoologische Mededelingen 69 (13): 139-151.

Kemp, S.W. 1925. On various Caridea. Notes on Crustacea Decapoda in the Indian Museum. XVII. Records of Indian Museum 27: 249-343.

Lenz, H. 1902. Die Crustaceen der Sammlung Plate (Decapoda und Stomatopoda). Part 3, vol. 2. In: Fauna Chilensis. Zoologische Jahrbücher 5 (Suppl.): 731-772.

Manning, R.B. 1961. Notes on the Caridean shrimp Rhynchocinetes rigens Gordon (Crustacea: Decapoda) in the western Atlantic. Notulae Naturae 348: 1-7.

McCulloch, A.R. 1909. Studies in Australian Crustacea, II. Records of the Australian Museum 7 (4): 305-314.

Mendez, M. 1981. Claves de identificación y distribución de los langostinos y camarones (Crustacea: Decapoda) del mar y rios de la costa del Perú. Boletin del Instituto marino del Perú 5: 1-170.

Miers, E.J. 1876. Catalogue of the stalk- and sessile-eyed Crustacea of New Zealand. London, 136p.

MiLne Edwards, H. 1837a.Histoire naturelle des Crustacés, comprenant I'anatomie, la phisiologie et la classification de ces animaux. Librarie Encyclopedique de Roret 2: 1-531.

Milne Edwards, H. 1837b. Les Crustacés. In: G. Cuvier (Ed.). Le règne animal, distribué d'aprés son organisation, pour servir de base à l'histoire naturelle des animaux et d'introduction à l'anatomie comparée. Paris, ed. 4, vol. 17, p. 1-278.

Milne Edwards, H. \& H. Lucas 1843. Crustacés. In: A. d'Orbigny,
Voyage dans I'Amerique Méridionale (Le Brésil, la République Argentine, la Patagonie, la République du Chili, la République de Bolivia, la République du Pérou) executé pendant les années 1826, 1827, 1828, 1829, 1830, 1831, 1832 et 1833. Paris, vol. 6, p. 1-37.

Miranda, O.B. \& I. Kong U. 1970. El camarón de mar em Antofagasta (Rhynchocinetes typus Milne Edwards, 1837) (Crustacea: Decapoda: Rhynchocinetidae). Biologia Pesquera de Chile 4: 41-63.

Nicolet, H. 1849. Crustáceos. In: C. Gay (Ed.). História fisica y politica de Chile segun documentos adquiridos en esta República durante doce años de residencia en ella y publicada bajo los auspícios del supremo gobierno. Zoologia 3: 115-318.

Okuno, J. 1996. Cinetorhynchus manningi, a new shrimp (Crustacea: Decapoda: Caridea: Rhynchocinetidae) from the western Atlantic. Proceedings of the Biological Society of Washington 109 (4):725-730.

Okuno, J. 1997. Crustacea Decapoda: Review on the genus Cinetorhynchus Holthuis, 1995 from the Indo-West Pacific (Caridea: Rhynchocinetidae), 31-58. In: Richer DE Forges (Ed.). Les Benthos des fonds meubles des lagons de Nouvelle Calèdonie (Sédimentologie, Benthos). Paris, Orstom, Études et Thèses, vol. 3.

Ortmannn, A.E. 1890. Die unter ordnung Natantia Boas: Die Dekapoden-Krebse des Strassburger Museums, mit besonderer Berücksichtung der von Herrn Dr. Döderlein bei Japan und bei dem Liu-Kiu-Inseln gesammelten und zim Strassburger M useum aufbewahrten Formen, I. Zoologische Jahrbucher Abteilung für Systematik, Geographie und Biologie der Thiere 5: 437-542

PoRTER, C.F. 1940 a. Algunos crustáceos de la costa Antofagasta. Revista Chilena de História Natural 44: 145-147.

PORTER, C.F. 1940b. Algunos crustáceos de la costa Antofagasta. Revista de la Universidad de Santiago 25 (3): 311-313.

PoRTER, C.F. 1941. Algunos crustáceos de la costa Antofagasta. Boletin del Museu de História Natural “Javier Prado" 5: 458-460.

Ramos-Porto, M M.\& P.A. Coelho 1998. Malacostraca-EucaridaCaridea (Alpheoidea excluded), p. 325-350. In: P.S. YounG (Ed.). Catalogue of Crustacea of Brazil. Rio de Janeiro, Museu Nacional, Série Livros 6.

Rathbun, M.J. 1910. The stalk-eyed Crustacea of Peru and the adjacent coast. Proceedings of the United States National Museum 38 (1766): 531-620.

Retamal, M.A. 1981. Catálogo Ilustrado de los Crustáceos Decápodos de Chile. Gayana, Zoologia 144: 1-100

Retamal, M.A. 1994. Los Decápodos de Chile. Concepción, Universidad de Concepción, Proyeto de desarrollo de la Docencia, 256p.

SHARP, B. 1893. Catalogue of the crustaceans in the Museum of the Academy of Natural Sciences of Philadel phia. Proceedings of the Academy of Natural Sciences of Philadelphia 1893: 104-127. 
Stebilng, T.R.R. 1917. South Africa Crustacea. Part IX. Annals of the South Africa Museum 17: 23-46.

Stebilng, T.R.R. 1920. South African Crustacea. Part X. Annals of the South Africa Museum 17 (4): 231-272.

UDEKEN D'ACOZ, C. 1999. Inventaire et distribution des Crustacés décapodes del'Atlantique nord-oriental, dela Méditerranée, et des eaux continentales adjacentes au nord de $250 \mathrm{~N}$. Paris. Muséum National d'Histoire Naturelle, Institut d'Ecologie et de gestion de la Biodiversité, Service du Patrimoine naturel 40: 1-383.

W HITE, 1857. List of the specimens of Crustacea in the collection of the British Museum. London,143p.

Received in 21.III.2006; accepted in 27.II.2007. 